\title{
Irrigation as an historical climate forcing
}

\author{
Benjamin I. Cook $\cdot$ Sonali P. Shukla \\ Michael J. Puma $\cdot$ Larissa S. Nazarenko
}

Received: 14 November 2013/ Accepted: 27 May 2014

(c) Springer-Verlag (outside the USA) 2014

\begin{abstract}
Irrigation is the single largest anthropogenic water use, a modification of the land surface that significantly affects surface energy budgets, the water cycle, and climate. Irrigation, however, is typically not included in standard historical general circulation model (GCM) simulations along with other anthropogenic and natural forcings. To investigate the importance of irrigation as an anthropogenic climate forcing, we conduct two 5-member ensemble GCM experiments. Both are setup identical to the historical forced (anthropogenic plus natural) scenario used in version 5 of the Coupled Model Intercomparison Project, but in one experiment we also add water to the land surface using a dataset of historically estimated irrigation rates. Irrigation has a negligible effect on the global average radiative balance at the top of the atmosphere, but causes significant cooling of global average surface air temperatures over land and dampens regional warming trends. This cooling is regionally focused and is especially strong in Western North America, the Mediterranean, the Middle East, and Asia. Irrigation enhances cloud cover and precipitation in these same regions, except for summer in parts of Monsoon Asia, where irrigation causes a reduction in monsoon season precipitation. Irrigation cools the surface, reducing upward fluxes of longwave radiation (increasing net longwave), and increases cloud cover, enhancing shortwave reflection (reducing net shortwave). The relative magnitude of these two processes causes regional increases
\end{abstract}

B. I. Cook $(\square) \cdot$ S. P. Shukla · L. S. Nazarenko NASA Goddard Institute for Space Studies, 2880 Broadway, New York, NY 10025, USA

e-mail: benjamin.i.cook@nasa.gov

M. J. Puma

Center for Climate Systems Research, Earth Institute, Columbia University, 2880 Broadway, New York, NY 10025, USA (northern India) or decreases (Central Asia, China) in energy availability at the surface and top of the atmosphere. Despite these changes in net radiation, however, climate responses are due primarily to larger magnitude shifts in the Bowen ratio from sensible to latent heating. Irrigation impacts on temperature, precipitation, and other climate variables are regionally significant, even while other anthropogenic forcings (anthropogenic aerosols, greenhouse gases, etc.) dominate the long term climate evolution in the simulations. To better constrain the magnitude and uncertainties of irrigation-forced climate anomalies, irrigation should therefore be considered as another important anthropogenic climate forcing in the next generation of historical climate simulations and multimodel assessments.

Keywords Climate modeling - Irrigation - Forcing · Historical simulations

\section{Introduction}

General circulation model (GCM) simulations of the historical period (1850-present) use observation based estimates of natural (e.g., solar variability, volcanic eruptions) and anthropogenic [e.g., anthropogenic aerosols, greenhouse gas (GHG) concentrations, land use, etc.] forcings to simulate the last 150 years of climate evolution. Historical simulations provide an important baseline for understanding the context of future climate change, are used to test climate system responses to specific forcings, and are required for detection and attribution studies. These experiments therefore form an integral part of the model intercomparisons organized in tandem with the Intergovernmental Panel on Climate Change (IPCC) assessment 
reports (e.g., Taylor et al. 2012). Recent historical modeling studies have addressed diverse topics, including the impact of anthropogenic aerosol emissions on North Atlantic climate variability (Booth et al. 2012), the role of the ocean in the recent surface warming hiatus (Kosaka and Xie 2013), and the detection and attribution of anthropogenically forced warming trends (Santer et al. 2013). One anthropogenic forcing that is typically not included in standard historical GCM simulations, including the IPCC model intercomparisons, is irrigation.

Irrigation is the single largest anthropogenic water use, accounting for $70 \%$ of global freshwater withdrawals and $90 \%$ of consumption (Siebert et al. 2010). Irrigation has expanded and intensified rapidly over the twentieth century, accelerating after 1950 with the increased exploitation of groundwater resources (Rodell et al. 2009; Scanlon et al. 2012; Wada et al. 2010), and the climate effects of irrigation have been broadly documented (e.g., in the review by Mahmood et al. 2013b). In areas where evapotranspiration rates are moisture limited, the addition of irrigation water shifts the surface energy balance to favor latent over sensible heating, decreasing the Bowen ratio and reducing soil and air temperatures (Kueppers et al. 2007; Sacks et al. 2009). This first order effect has been documented primarily in areas characterized by growing seasons with low moisture availability and high atmospheric demand, such as the Central Valley of California (Bonfils and Lobell 2007) and the southern Great Plains (Barnston and Schickedanz 1984). Enhanced evapotranspiration from irrigation can also increase atmospheric water vapor, with potential consequences for the regional and global radiative balance. For example, Boucher et al. (2004) found that irrigation, when added to a GCM, acted as a net positive radiative forcing due to the enhanced trapping of longwave radiation from increased humidity, an effect that may be enough to increase local minimum temperatures (Mahmood et al. 2013a). Alternatively, if increased evapotranspiration from irrigation also enhances cloud formation, this may reduce the net solar forcing at the surface or top of the atmosphere (TOA) by increasing albedo and shortwave reflection. Finally, although large uncertainties remain, there is evidence that irrigation may even enhance precipitation locally and downwind of major irrigation regions (e.g., Barnston and Schickedanz 1984; DeAngelis et al. 2010; Lo and Famiglietti 2013).

There is clear evidence that irrigation has important local, regional, and possibly global effects on climate. Despite this, irrigation is typically not included as an anthropogenic forcing in historical GCM simulations along with land cover change, aerosols, GHGs, and other forcings. Here, we conduct a new suite of historical GCM experiments with the Goddard Institute for Space Studies (GISS) atmosphere GCM, ModelE2 (Schmidt et al. 2014), coupled to the Russell ocean model (Russell et al. 1995) and using historically estimated irrigation rates from the dataset of Wisser et al. (2010). Ours is the first GCM study of irrigation to quantify the importance of irrigation as a climate forcing in the context of other natural and anthropogenic forcings during the climate evolution of the twentieth century, using the same framework as the forced historical simulations from the Coupled Model Intercomparison Project version 5 (CMIP5, Taylor et al. 2012).

\section{Data and methods}

\subsection{GISS ModelE2}

All experiments are conducted with the coupled GCM ModelE2-R $\left(2^{\circ} \times 2.5^{\circ} \quad\right.$ latitude/longitude resolution $)$, which includes the latest version of the state-of-the-art GISS atmosphere general circulation model (ModelE2), with updated physics for inclusion in the CMIP5 (Schmidt et al. 2014), and the Russell (R) ocean model (Hansen et al. 2007; Russell et al. 1995). Historical simulations using current (Miller et al. 2014) and previous (Hansen et al. 2007) versions of the model demonstrate the ability of ModelE2 to realistically reproduce historical responses to external climate forcings, including volcanic eruptions and anthropogenic GHGs. For our experiments, we use the version of model physics with non-interactive atmospheric composition (referred to as NINT in Miller et al. 2014), where concentrations of ozone and radiatively important aerosols are prescribed according to observation based decadal averages.

The irrigation module in ModelE2-R uses historically varying, monthly irrigation rates from a $0.5^{\circ}$ resolution reconstruction of twentieth century global hydrography (Wisser et al. 2010). Wisser et al. (2010) derive historical irrigation rates from 1901 to 2002 using the University of Frankfurt/FAO Global Maps of Irrigated Areas (Siebert et al. 2005a, b) (extended back to 1901 by Freydank and Siebert 2008) and an offline model of terrestrial water balance and transport (WBMplus; Federer et al. 2003; Vörösmarty et al. 1998). WBMplus includes explicit representations of human activities that affect the water cycle: irrigation (Wisser et al. 2008) and reservoir operation (Wisser et al. 2010). For areas equipped for irrigation in WBMplus, an irrigation water flux is applied to the soil to compensate for climate observation forced soil moisture deficits, including an explicit treatment for paddy rice irrigation. In ModelE2-R, this new irrigation flux of water, calculated offline in WBMplus, is added to the top of the vegetated fraction of the soil column, below the vegetation canopy. Without a separate soil column for the irrigated crop fraction, irrigation is applied to the total vegetated 
Fig. 1 Annual average irrigation rates $\left(\mathrm{mm} \mathrm{day}^{-1}, \log \right.$ scale) for a 1901-1920 and b $1981-2000$

\section{Annual Irrigation Rates (mm day $\left.{ }^{-1}\right)$}
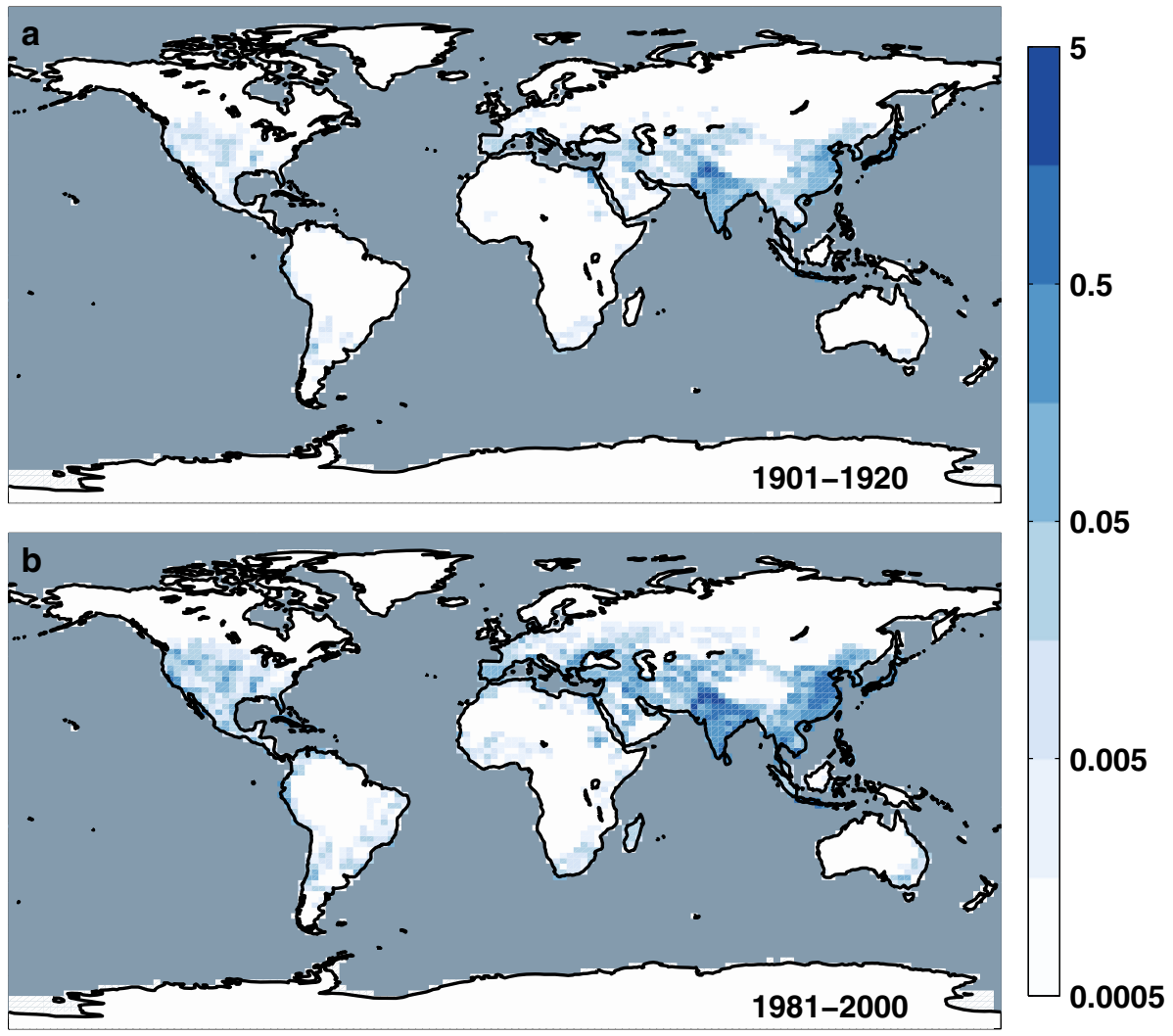

fraction. The implications of this simplification are addressed in the discussion section of this paper. Previous studies with the GISS model have used the irrigation module to investigate irrigation impacts on climate during the historical period (Puma and Cook 2010; Shukla et al. 2013) and under increased GHG forcing (Cook et al. 2011). Because our model simulations for this study begin in 1850, we linearly extrapolated the model irrigation from 1901 back to 1850 . Further details on the development of the underlying irrigation dataset, and its implementation in ModelE2-R, can be found in Wisser et al. (2010) and Puma and Cook (2010), respectively.

Irrigation is concentrated in the major regions of agricultural production in the Northern Hemisphere (Fig. 1). In the early part of the century (1901-1920, Fig. 1a), most irrigation occurs in Monsoon Asia, with secondary centers in the Mediterranean, the Middle East, and North America. By the end of the twentieth century (1981-2000, Fig. 1b), irrigation rates intensify in these areas, and expand into additional regions, such as Northern Europe and Central Asia. Differences between the early and late twentieth century irrigation maps reflect the steady increase in global irrigation rates over the last 100 years (Fig. 2a), with a notable acceleration after about 1950 that coincides with the start of the green revolution and exploitation of groundwater resources. The vast majority of global irrigation is concentrated in Monsoon Asia (Fig. 2b), where water intensive rice cultivation dominates the agricultural landscape. In North America there is a notable jump at 1950, coinciding with the start of exploitation of the Ogallala aquifer (Scanlon et al. 2012). Over the European domain (Fig. 2d), irrigation increases over the course of the twentieth century before plateauing in the 1980s.

\subsection{Experiments}

We conduct two 5-member ensemble experiments with ModelE2-R from 1850-2000, with initial conditions taken from a near-equilibrium pre-industrial control run with atmospheric composition and solar irradiance held fixed at 1850 values. In experiment HIST, all forcings are identical to those used in the standard ModelE2-R historical simulations submitted for the CMIP5 effort (Miller et al. 2014), including solar and volcanic forcing, anthropogenic GHGs, land cover, and tropospheric aerosols (natural and anthropogenic). In experiment HIST + IRR we include, as an additional forcing, transient historical irrigation rates, as described previously. Differences between the two experiments (HIST + IRR - HIST) are used to assess the climatic impact of irrigation. Because we are interested in the 
Annual Irrigation, $\mathbf{k m}^{3}$
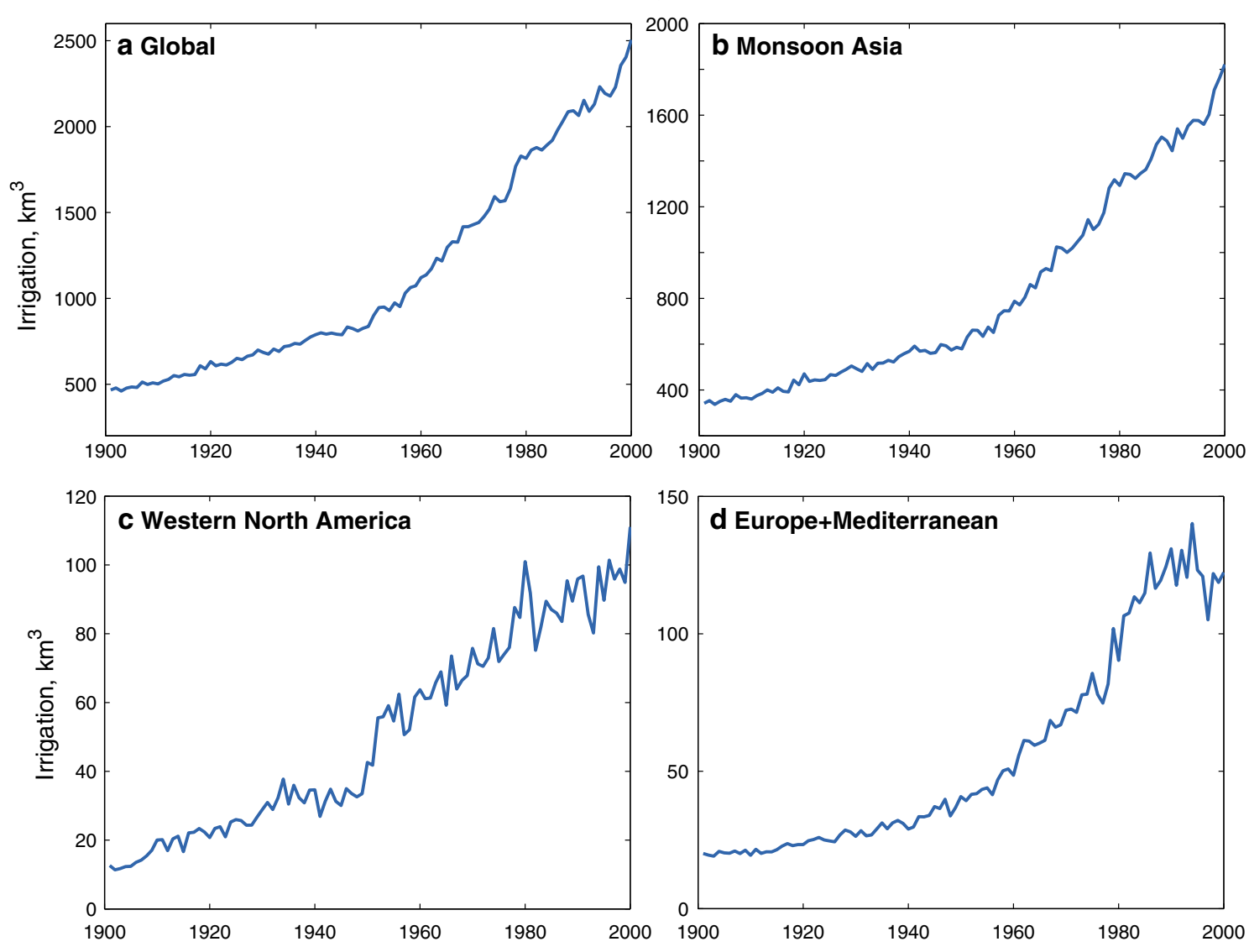

Fig. 2 Annual irrigation $\left(\mathrm{km}^{3}\right)$ from 1901-2000: a global, b Monsoon Asia $\left(60^{\circ} \mathrm{E}-130^{\circ} \mathrm{E}, 5^{\circ} \mathrm{N}--40^{\circ} \mathrm{N}\right)$, c Western North America $\left(125^{\circ} \mathrm{W}--90^{\circ} \mathrm{W}, 30^{\circ} \mathrm{N}--45^{\circ} \mathrm{N}\right)$, and $\mathbf{d}$ Europe and the Mediterranean $\left(13^{\circ} \mathrm{W}--40^{\circ} \mathrm{E}, 30^{\circ} \mathrm{N}--70^{\circ} \mathrm{N}\right)$

forced response, all analyses are based on the ensemble mean from each model experiment. Statistical differences in the mean and median between the two simulations are assessed using the two-sided Student's $t$ test and Wilcoxon rank sum test, respectively. We focus our analyses primarily on the latter part of the twentieth century when irrigation rates, and their accompanying climate impacts, are largest. Unless otherwise noted, all anomalies (time series plots) are relative to the pre-industrial control run from which the initial conditions were taken and $\Delta$ refers to differences between the two experiments (HIST + IRR -HIST) for 1981-2000.

\section{Results}

\subsection{Global average response}

In both experiments, the historical evolution of net radiation (Rnet) at the TOA follows the expected increase from enhanced GHG forcing and trapping of outgoing longwave radiation (Fig. 3a). Large magnitude, but short-lived, negative spikes in Rnet correspond to volcanic eruptions and the associated negative aerosol forcing. At the TOA, Rnet is about $+0.02 \mathrm{~W} \mathrm{~m}^{-2}$ higher in HIST + IRR compared to HIST, similar to the magnitude of irrigation forcing $\left(+0.03 \mathrm{~W} \mathrm{~m}^{-2}\right)$ found in the experiments of Boucher et al. (2004). Irrigation forcing at the TOA in our experiments is insignificant $(p>0.05)$, however, suggesting that irrigation has a negligible effect on the global TOA radiative balance. It should be noted, though, that the standard radiative forcing concept might be difficult to apply to irrigation because of the temperature, energy balance, and water vapor feedbacks inherent in the irrigation-climate response (Boucher et al. 2004).

Irrigation has a cooling effect on global average land + ocean surface air temperatures (Fig. 3b), but differences between the two simulations are small and insignificant $\quad\left(p>0.05 ; \Delta T_{\text {mean }}=-0.07 \mathrm{~K}, \Delta T_{\text {median }}=\right.$ $-0.08 \mathrm{~K})$. If the temperature average is calculated for land areas only, however, the cooling effect is larger and 
Global Average Anomalies, Land+Ocean
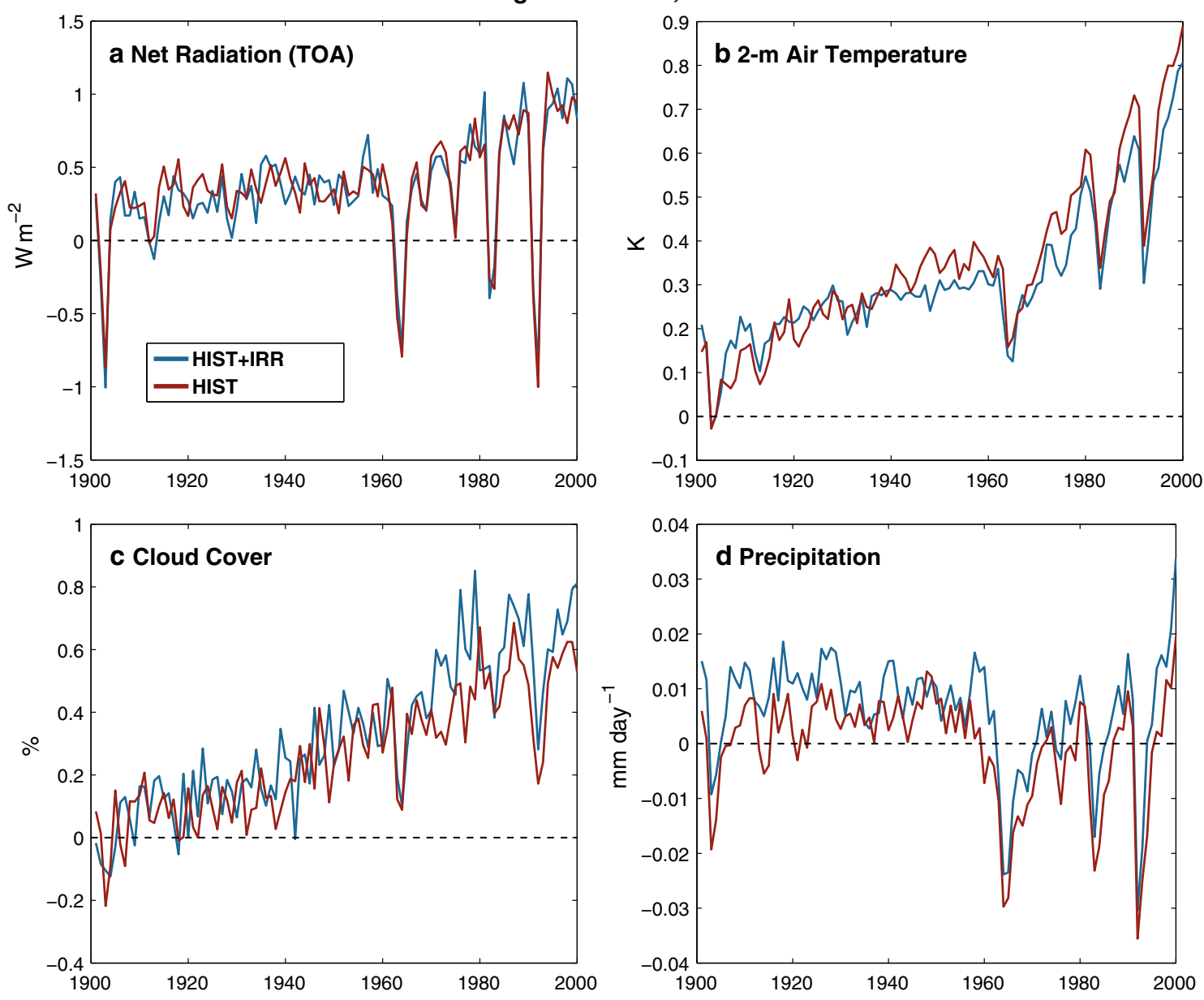

Fig. 3 Annual, globally (land and ocean) averaged anomalies of a net radiation at the top of the atmosphere $\left(\mathrm{W} \mathrm{m}^{-2}\right), \quad$ b $2-\mathrm{m}$ air temperature $(\mathrm{K})$, c cloud cover $(\%)$, and d precipitation $\left(\mathrm{mm} \mathrm{day}^{-1}\right)$ for the ensemble averages of HIST and HIST + IRR.

significant $\left(\Delta T_{\text {mean }}=-0.17 \mathrm{~K}, p<0.02 ; \Delta T_{\text {median }}=-0.14 \mathrm{~K}\right.$, $p<0.04)$. This is a larger cooling effect than found in previous 'realistic' irrigation experiments. For example, land based cooling in Boucher et al. (2004) was only $-0.05 \mathrm{~K}$ and previous irrigation experiments with ModelE using prescribed SSTs only caused cooling of $-0.10 \mathrm{~K}$ (Puma and Cook 2010). Sacks et al. (2009) actually found a slight net annual warming $(+0.015 \mathrm{~K})$, as dynamically induced warming during the winter balanced irrigation induced cooling during the summer $(-0.06 \mathrm{~K})$ and fall $(-0.04 \mathrm{~K})$. Cloud cover increases are highly significant in HIST + IRR $(p<0.001)$ over global land and ocean areas, with greater increases over land. Precipitation in HIS$\mathrm{T}+\mathrm{IRR}$ also increases over land and ocean in the irrigation run, but this increase is only marginally significant $(p<0.10)$.

Anomalies are relative to a 41-year average from the pre-industrial control run used to generate the initial conditions for all ensemble members

\subsection{Temperature trends}

Increasing irrigation rates over the twentieth century cause significant differences in regional temperature trends. Both HIST (Fig. 4a) and HIST + IRR (Fig. 4b) show widespread and significant warming in annual average surface air temperatures from 1971 to 2000 (insignificant differences at $p>0.05$ in Fig. 4 have been masked out). In many areas with major irrigation expansion or intensification, however, these warming trends weaken (Western North America), become insignificant (Europe), or, in some cases, reverse to cooling trends (extra-tropical South America, India).

The time when irrigation begins to significantly affect surface air temperature varies by region. In Central Asia and China (Fig. 5a, b), temperatures in the two simulations 
Fig. 4 Ensemble average annual surface air temperature trends (1971--2000, K year ${ }^{-1}$ ) from the a HIST and $\mathbf{b}$ HIST + IRR simulations. Insignificant trends $(p>0.05)$ have been masked out 2-m Temp Trends (1971-2000, $\mathrm{K} \mathrm{yr}^{-1}$ )
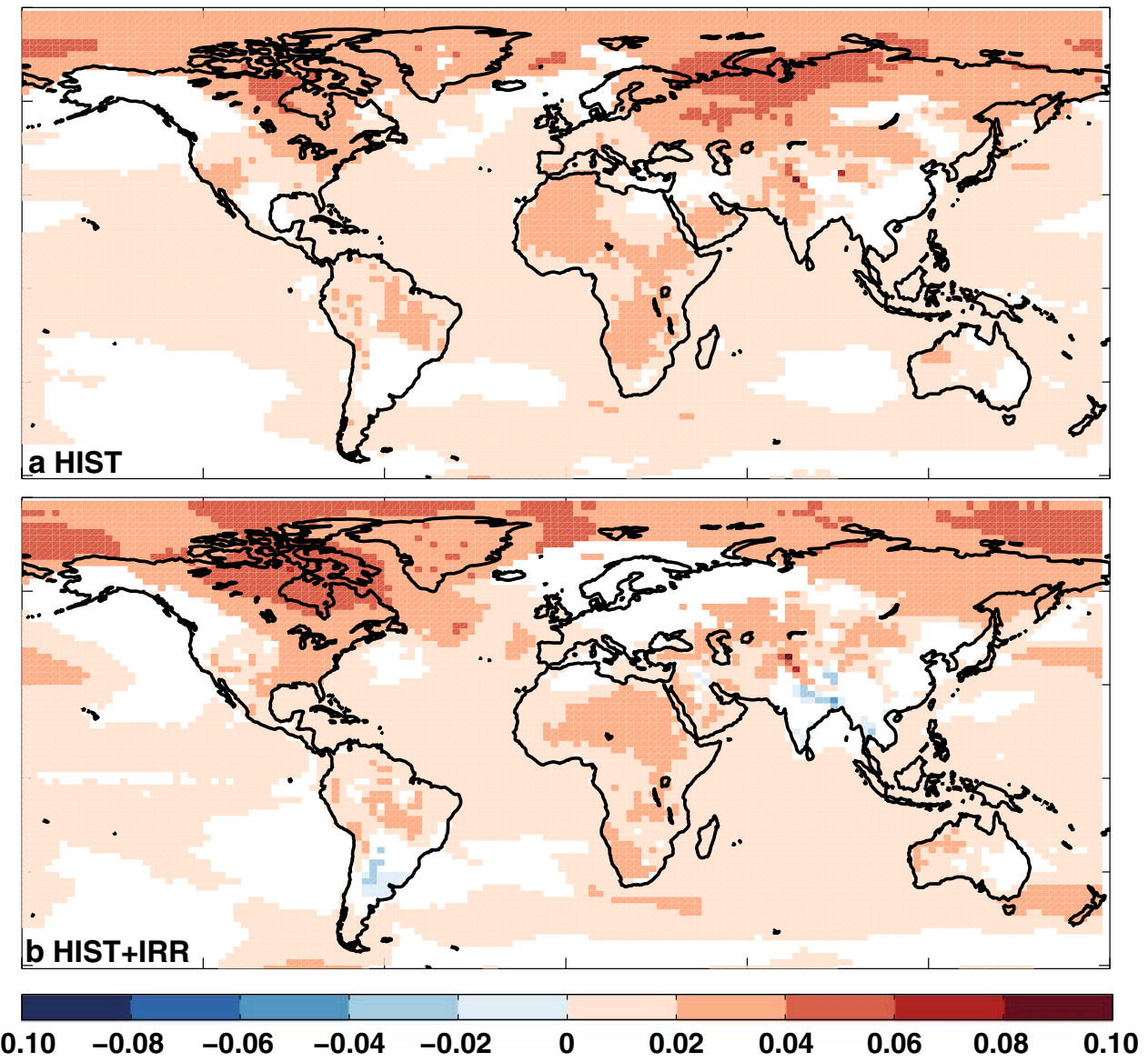

begin to diverge after about 1950. Both regions show warming up to the 1950 s, followed by multi-decadal cooling often ascribed to increased aerosol forcing (e.g., He et al. 2013; Qian and Giorgi 2000). Despite the temperature offset, both regions have similar temperature trends over 1971-2000. This contrasts sharply with India (Fig. 5c), where irrigation rates are high enough across the whole century to lead to continuously cooler surface temperatures in HIST + IRR. Temperatures trends do diverge over India, with increasing irrigation causing a slight cooling trend over the last 30 years of the century. Late twentieth century temperature trends are similar between the HIST and HIST + IRR simulations for the Mediterranean (Fig. 5d), the Middle East (Fig. 5e), and Western North America (Fig. 5f). Cooler average temperatures in HIS$\mathrm{T}+$ IRR manifest in the Mediterranean and Western North America beginning in the 1970s and in the 1930s in the Middle East.

\subsection{Spatial response: 1981-2000}

Irrigation effects on climate in the late twentieth century (1981-2000) are highly localized, coinciding with land areas where irrigation is most intense. Irrigation causes widespread cooling (Fig. 6a), primarily over Western North America, the Mediterranean, the Middle East, India, Indochina, Central Asia, and China. Localized cooling is generally on the order of -0.5 to $-1.0 \mathrm{~K}$, with much more intensive cooling over northern India, where the highest irrigation rates in the model and irrigation dataset occur. Irrigation increases atmospheric moisture, primarily at low levels, and this is reflected in the $850 \mathrm{hPa}$ specific humidity (Fig. 6b) and low level (surface to $680 \mathrm{hPa}$ ) cloud cover (Fig. 6c). In concert with these humidity increases, precipitation is also enhanced (Fig. 6d), especially in Western North America, the Middle East, and Central Asia. The only major region where annual land precipitation significantly declines is in far eastern India, Bangladesh, and Myanmar in Monsoon Asia due to drying during the summer monsoon.

Despite little impact on the globally averaged radiative balance, irrigation has a large effect on regional radiative fluxes (Fig. 7). Significant changes in net total radiation at the surface (Fig. 7a) and TOA (Fig. 7b) occur primarily over Monsoon and Central Asia. Over the Indian subcontinent and Southeast Asia, net radiation increases, while 


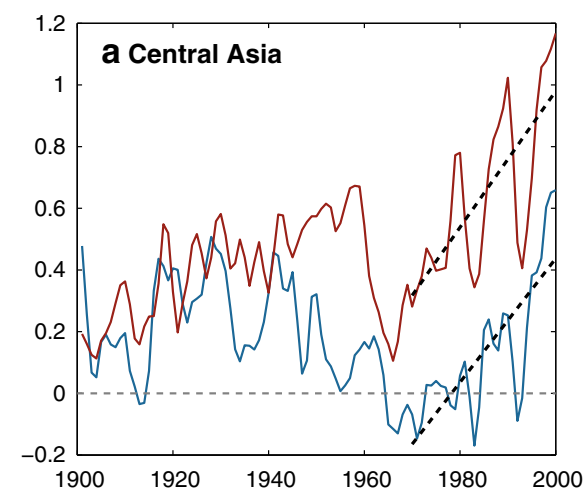

\section{2-m Air Temperature Anomalies (K)}
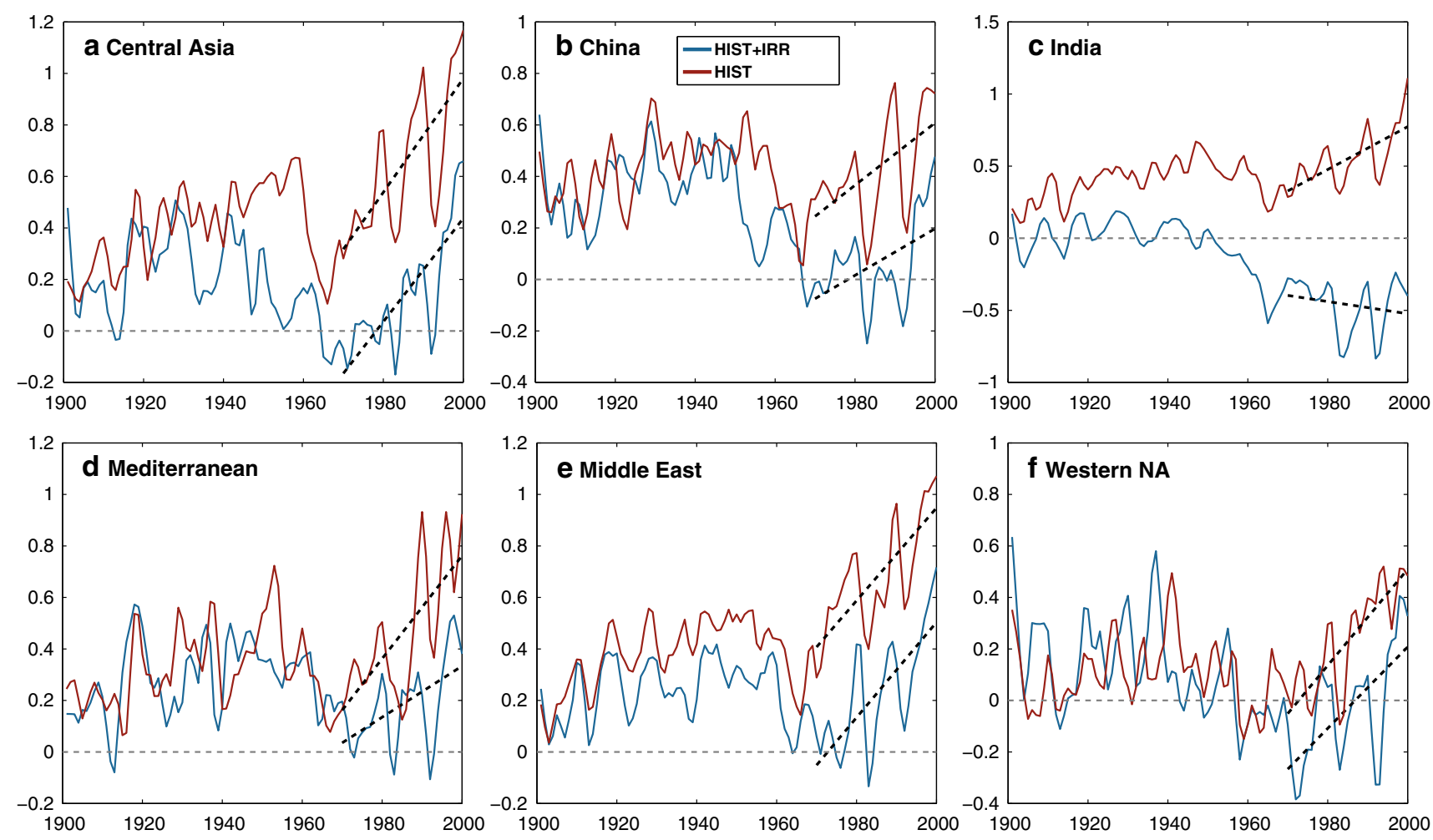

Fig. 5 Regional ensemble average annual surface temperature anomalies (K) from major irrigation regions: a Central Asia $\left(72^{\circ} \mathrm{E}--98^{\circ} \mathrm{E}, 35^{\circ} \mathrm{N}--45^{\circ} \mathrm{N}\right)$, b China $\left(100^{\circ} \mathrm{E}-130^{\circ} \mathrm{E}, 20^{\circ} \mathrm{N}--45^{\circ} \mathrm{N}\right)$, c India $\left(70^{\circ} \mathrm{E}--95^{\circ} \mathrm{E}, 5^{\circ} \mathrm{N}--35^{\circ} \mathrm{N}\right)$, d the Mediterranean $\left(13^{\circ} \mathrm{W}--30^{\circ} \mathrm{E}, 30^{\circ} \mathrm{N}--45^{\circ} \mathrm{N}\right)$, e Middle East $\left(31^{\circ} \mathrm{E}--68^{\circ} \mathrm{E}, 10^{\circ} \mathrm{N}--44^{\circ}\right.$ $\mathrm{N})$, and f Western North America $\left(125^{\circ} \mathrm{W}--90^{\circ} \mathrm{W}, 30^{\circ} \mathrm{N}--45^{\circ} \mathrm{N}\right)$.

Temperature curves are smoothed with a 5-year lowess filter to emphasize long term trends and variability. Black dashed lines are the best fit linear regression lines from 1971 to 2000, based on a fit to the unsmoothed ensemble average temperatures. Anomalies are relative to a 41-year average from the pre-industrial control run used to generate the initial conditions for all ensemble members

over Central Asia and China net radiation decreases. Irrigation reduces net shortwave at TOA (Fig. 7c) and the surface (Fig. 7d), especially over Western North America, the Middle East, and Asia. These reductions coincide closely with the increases in cloud cover (Fig. 6c), indicating this change is through increased reflection by clouds. Indeed, areas where net shortwave is actually increasing (e.g., northern India) are areas where cloud cover declines. Irrigation increases net longwave fluxes (Fig. 7e, f). In ModelE2-R this occurs because the cooler soil temperatures reduce outgoing longwave fluxes; increased longwave trapping from enhanced near surface humidity is small (not shown). Over North America, the longwave and shortwave effects largely cancel, leading to negligible changes in net radiation. In India, the enhanced longwave dominates, increasing net total radiation, while in Central Asia and China, the shortwave reductions drive an overall decline in energy availability.
Irrigation has a much larger impact on surface energy partitioning (sensible, Fig. 8a, and latent, Fig. 8b) than on total energy availability in our experiments. In areas where irrigation rates are high (Western North America, the Mediterranean, Middle East, India), the addition of irrigation water shifts the Bowen ratio to favor latent over sensible heating, and these shifts coincide closely with much of the surface cooling in Fig. 6a. Outside the main irrigation regions, significant increases in latent heating and reductions in sensible heating are related to local increases in precipitation (e.g., the Sahara; Fig. 6d). The dominance of Bowen ratio versus energy balance shifts for the temperature response in our experiments contrasts sharply with the irrigation study of Sacks et al. (2009). In their study, Sacks et al found instead that the cooling response was driven primarily by irrigation-induced increases in cloud cover and reductions in surface shortwave radiation, rather than by direct evaporative cooling. 

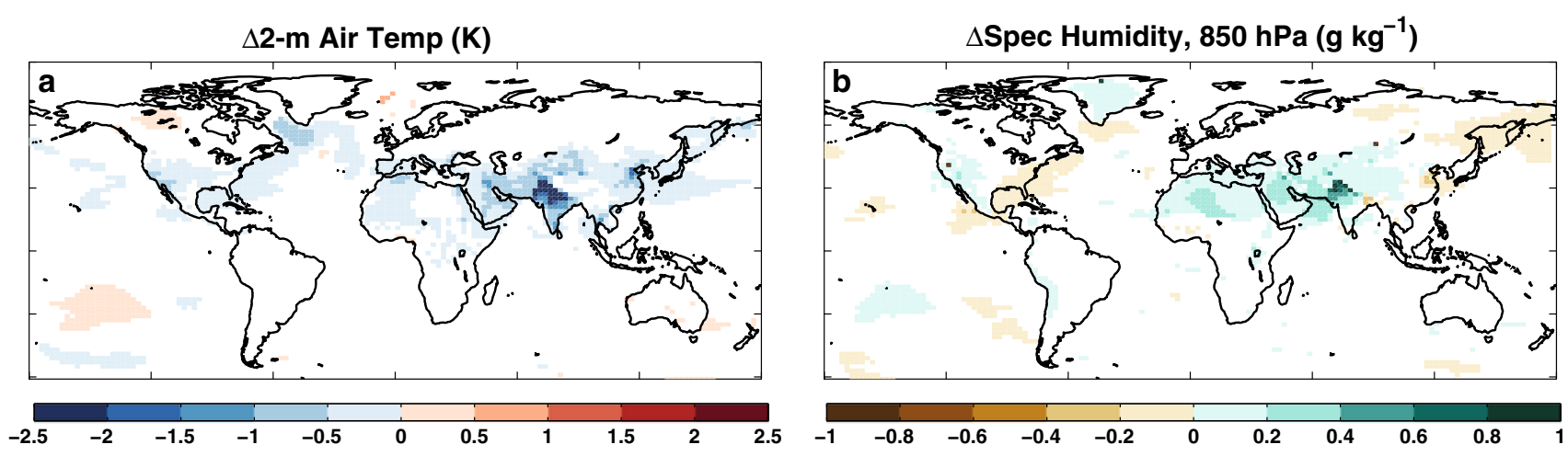

$\Delta$ Low Cloud Cover (\%)

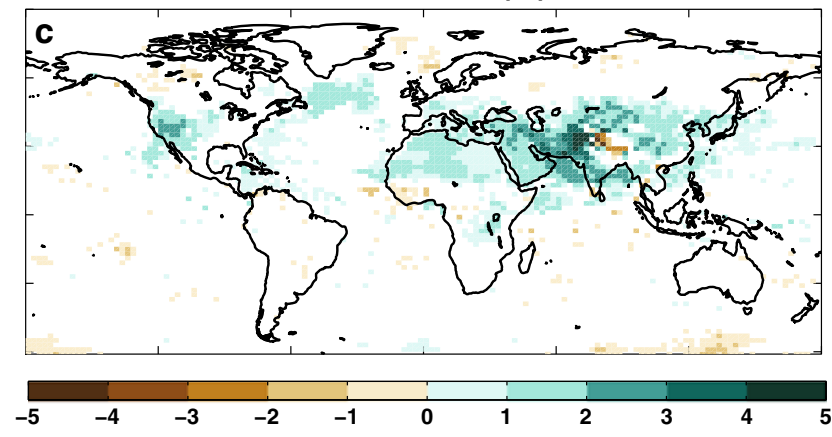

Fig. 6 Irrigation effects (HIST + IRR - HIST) on a 2-m surface air temperature, b specific humidity at $850 \mathrm{hPa}$, c low cloud cover (surface to $680 \mathrm{hPa}$ ), and d precipitation. Differences are based in the

\subsection{Regional and seasonal effects}

Highest irrigation rates occur in Asia, and this is where the largest temperature and precipitation responses occur (Fig. 9). In the relatively temperate mid-latitude regions of China (Fig. 9, top row) and Central Asia (Fig. 9, middle row), irrigation is highest during boreal summer, and it is during the warm months that most of the significant cooling occurs (indicated by red stars, $p \leq 0.05$, two-sided Student's $t$ test). Irrigation significantly enhances warm season precipitation in June in China and during May, June, August, and September in Central Asia. Irrigation rates are much higher over the region of India + Bangladesh, with larger (and significant) magnitude temperature and precipitation anomalies in most months (Fig. 9, bottom row). This is partly due to the more sub-tropical nature of this region, characterized by relatively high evaporative demand throughout the year and a pronounced dry season during boreal winter. Most cooling in India + Bangladesh occurs during this dry season, but precipitation responses are seasonally dependent. Precipitation increases are small, but significant, during the dry season, and are likely linked to increased evapotranspiration from irrigation during the relatively warm dry season. During the main summer

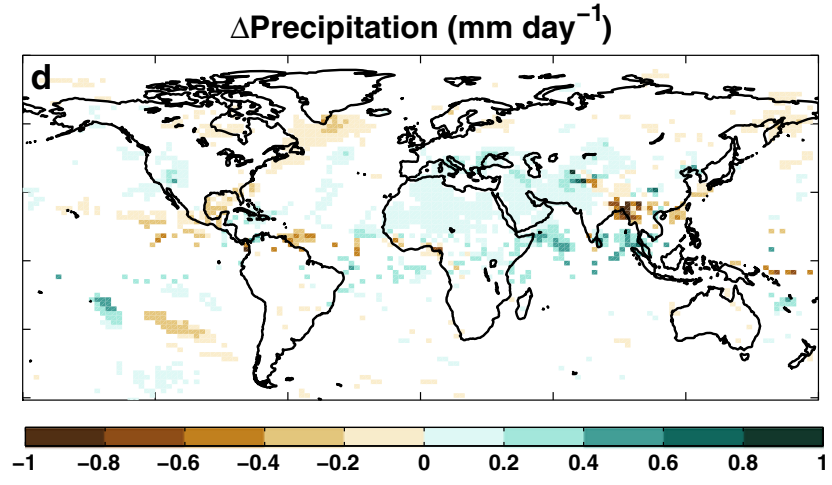

ensemble means of each experiment for 1981-2000. Insignificant differences ( $p>0.05$, two-sided Student's $t$ test) have been masked out

monsoon season, precipitation deficits are large and concentrated in eastern India and Bangladesh. These changes may be related to the tendency for irrigation to weaken the summer monsoon circulation in this region (discussed in detail in Shukla et al. 2013). An analysis of the surface energy balance partitioning in these regions (Fig. 10) indicates that the temperature changes are due primarily to changes in the Bowen ratio, rather than total energy availability. In China and India + Bangladesh, significant changes in net radiation at the surface (Fig. 10, left column) are all positive, indicating the dominance of the longwave effects, while in Central Asia increased shortwave reflection causes a net reduction in surface energy. These changes in net energy availability, however, are much smaller than the changes in latent (Fig. 10, center column) and sensible (Fig. 10, right column) heat fluxes.

Irrigation also has a large and significant impact on climate in the Mediterranean (Fig. 11, top row), Middle East (Fig. 11, middle row), and Western North America (Fig. 11, bottom row). These three regions are generally characterized by warm summers with high evaporative demand and, as with China and Central Asia, the warm season is when the temperature (cooling) and precipitation (enhanced) responses are largest. Notably, precipitation 

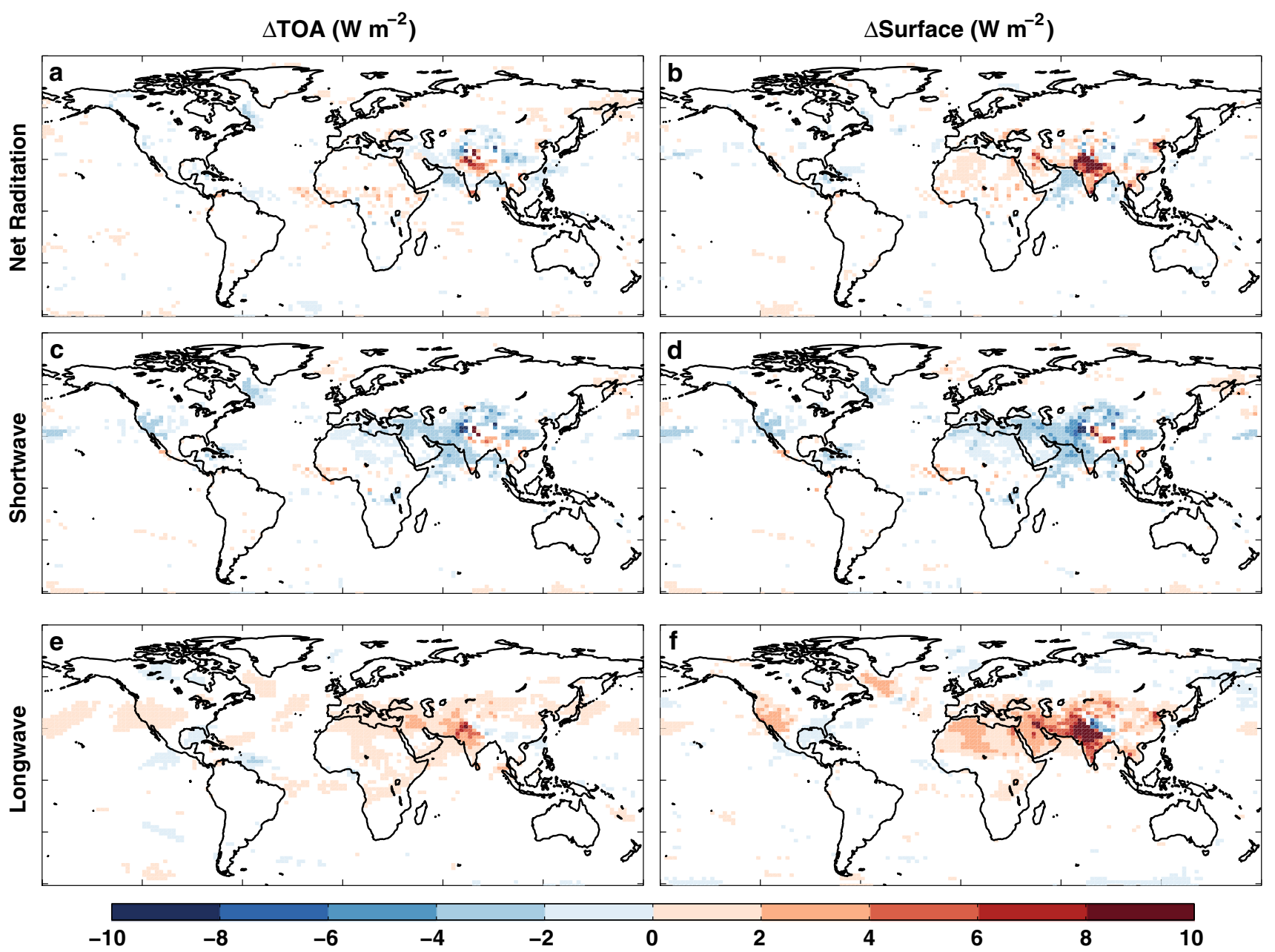

Fig. 7 Same as Fig. 6, but for net total radiation at the a top of the atmosphere and $\mathbf{b}$ surface, net shortwave radiation at the $\mathbf{c}$ top of the atmosphere and $\mathbf{d}$ surface, and net longwave radiation at the $\mathbf{e}$ top of the atmosphere and $\mathbf{f}$ surface

increases in Western North America occur during JulyAugust-September, the same season of enhancement found in the irrigation experiments of Lo and Famiglietti (2013). Irrigation causes some net increases in net radiation (Fig. 12, left column) in the Mediterranean and Middle East, but the shortwave and longwave effects cancel out over Western North America. As with Asia, shifts in latent (Fig. 12, center column) and sensible (Fig. 12, right column) heat fluxes are much larger than any changes in net energy availability.

\section{Discussion and conclusions}

Human land use and land cover change is an important anthropogenic climate forcing (Mahmood et al. 2013b), with regional impacts that may match or even exceed localized responses to globally well-mixed anthropogenic
GHG forcing (Pielke et al. 2011). But while the effects of land cover change on historical and future climate have been comprehensively assessed (e.g., Feddema et al. 2005; Kumar et al. 2013; Pitman et al. 2009), only recently have studies begun to analyze the response of the climate system to second order land use effects (Luyssaert et al. 2014). This includes cropland management (Lobell et al. 2006), crop growth and development (Chen and Xie 2012), and irrigation (Lobell et al. 2006; Sacks et al. 2009). In this study, we use a new set of historically forced GCM experiments to investigate the importance of irrigation as an historical climate forcing.

Compared to other regionally important anthropogenic forcings, such as land cover change (Boisier et al. 2012) or aerosols (e.g., Bellouin et al. 2013; Booth et al. 2012), irrigation has relatively small effects on the total energy availability at the surface or TOA for most areas. Significant perturbations to net total radiation are largely 
Fig. 8 Same as Fig. 6, but for a surface sensible heat flux and b surface latent heat flux
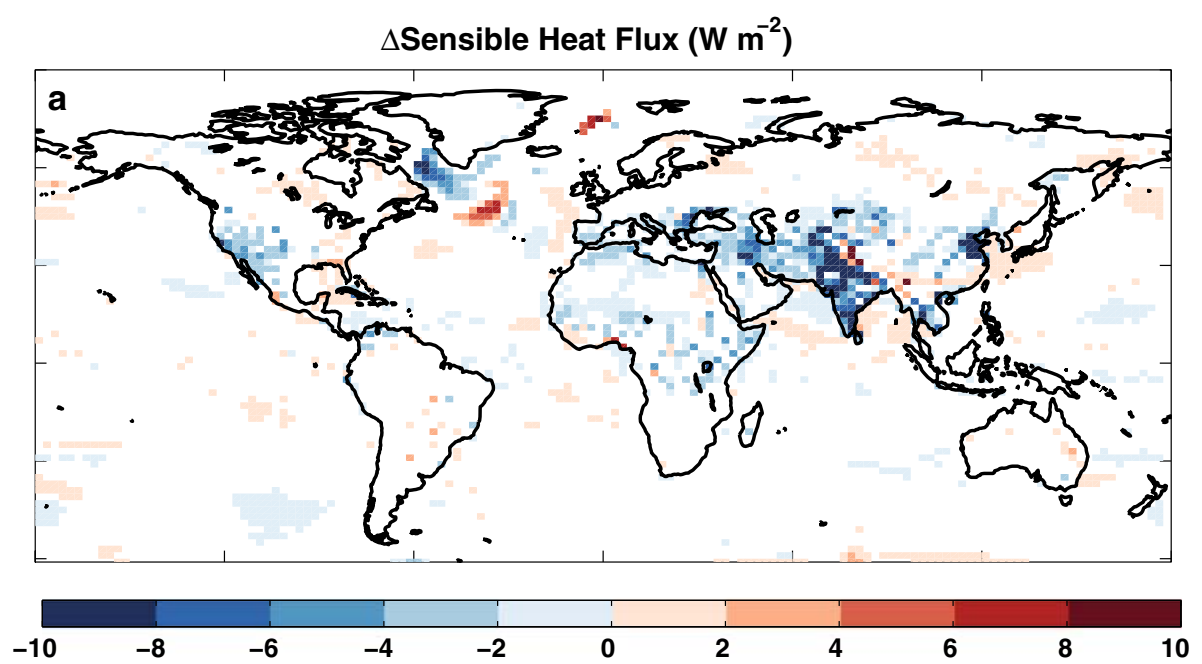

$\Delta$ Latent Heat Flux $\left(\mathrm{W} \mathrm{m}^{-2}\right)$
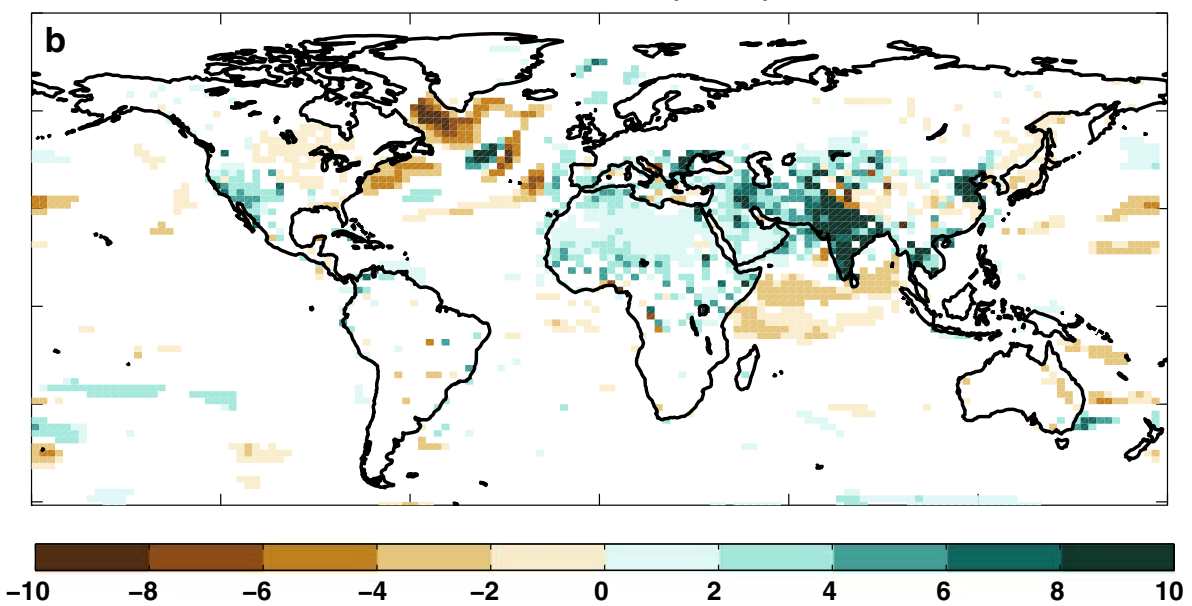

confined to Asia (Fig. 7a,b), and range between about -4 (e.g., Central Asia and China at TOA) to +10 (e.g., India at the surface) $\mathrm{W} \mathrm{m}^{-2}$, depending on whether shortwave or longwave effects dominate. Instead, irrigation has a much larger and widespread influence on the surface partitioning between sensible and latent heat fluxes (Fig. 8). It is these shifts in the Bowen ratio that cause widespread regional cooling and enhancement of precipitation, with climate responses generally scaling with the intensity of irrigation. The small impact of irrigation on net energy availability is perhaps not surprising, given that the addition of irrigation does not directly add substantial amounts of energy to the global earth system. Any changes in net radiation must then come from secondary effects (e.g., cloud cover changes, increased atmospheric water vapor, etc.) which, as noted, were small at the global scale.

Contrary to observations (e.g., Jones et al. 2012), warming trends in HIST + IRR from 1971 to 2000 become insignificant or actually reverse in Northern Europe and India, suggesting that climate in ModelE2-R is overly sensitive to irrigation, at least in certain regions. This overestimation of irrigation effects on climate, and the subsequent divergence between our GCM simulations and observed warming trends, could occur for a variety of reasons. First, the magnitude of climate responses to irrigation depends crucially on the evaporative regime, i.e. the degree to which evapotranspiration rates are energy (demand) versus moisture (supply) limited (Cook et al. 2011; Puma and Cook 2010). The extent to which models 

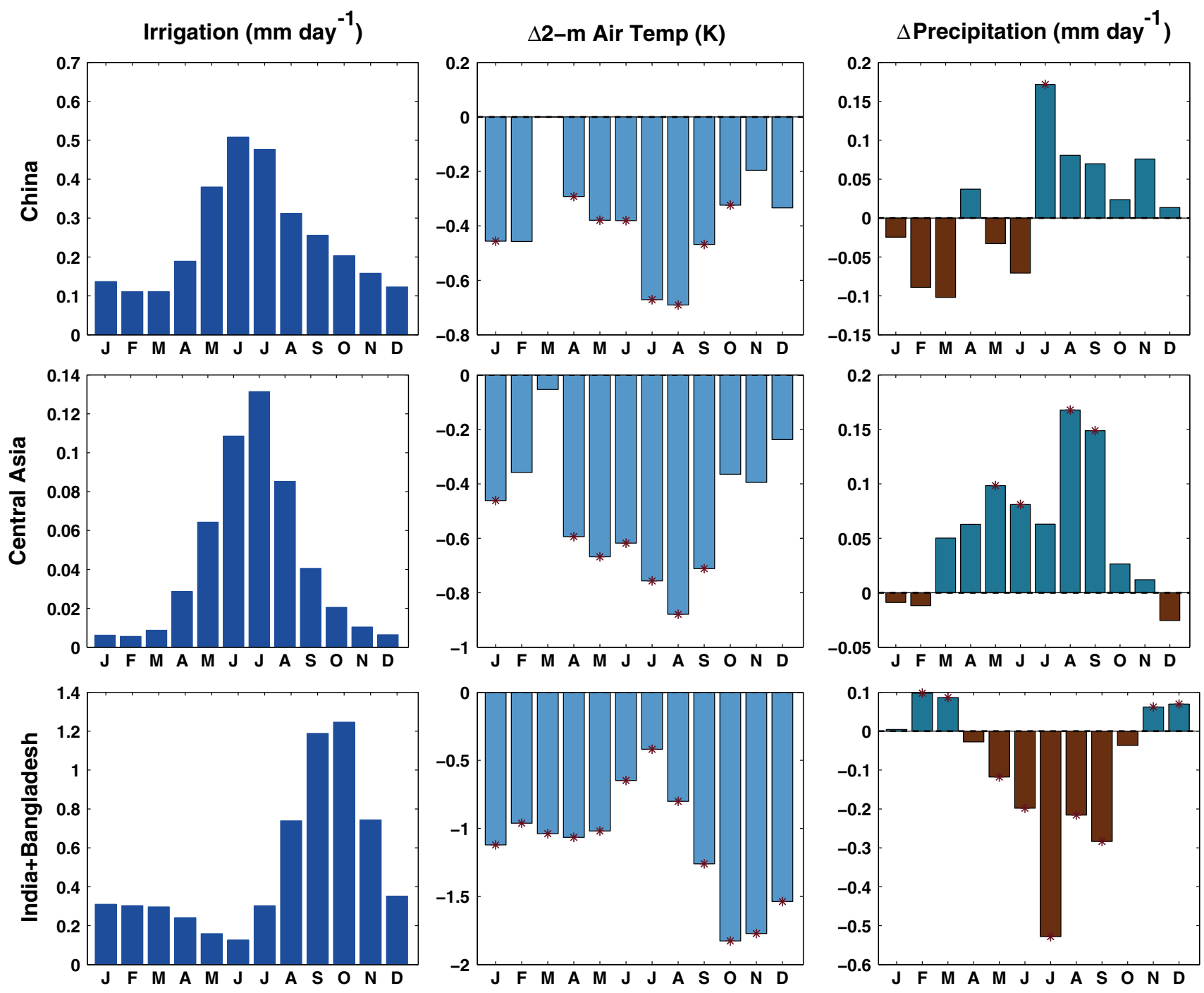

Fig. 9 For China $\left(100^{\circ} \mathrm{E}-130^{\circ} \mathrm{E}, 20^{\circ} \mathrm{N}--45^{\circ} \mathrm{N}\right.$, top row $)$, Central Asia $\left(72^{\circ} \mathrm{E}--98^{\circ} \mathrm{E}, 35^{\circ} \mathrm{N}--45^{\circ} \mathrm{N}\right.$, middle row), and India $\left(70^{\circ} \mathrm{E}--95^{\circ} \mathrm{E}, 5^{\circ} \mathrm{N}--35^{\circ} \mathrm{N}\right.$, bottom row $)$, monthly irrigation rates in the HIST + IRR ensemble (left column), and monthly differences (HIST + IRR - HIST) in 2-m air temperature (center column) and

precipitation (right column). Differences are calculated using the ensemble averages for 1981-2000. Significant differences at the $p \leq 0.05$ level, based on a two-sided Student's $t$ test, are indicated by the red stars

can accurately simulate observed evaporative regimes, however, is affected by numerous model dependent factors, including precipitation biases and land surface parameterizations (e.g., rooting depth, vegetation seasonality, etc.). Ultimately, if model soils are too dry compared to the real world, irrigation will have a larger effect on evapotranspiration and the subsequent climate response will be amplified. Relatedly, land-atmosphere coupling strengths are known to vary widely across GCMs (Koster et al. 2006). Second, models with lower resolution than the

original irrigation dataset $\left(0.5^{\circ}\right)$ may amplify irrigationclimate responses (Puma and Cook 2010; Sacks et al. 2009). For this study, the underlying irrigation dataset was aggregated to the coarser resolution $\left(2^{\circ} \times 2.5^{\circ}\right)$ of ModelE2-R by summing all irrigation grid cells that would fall within each coarser ModelE2-R grid cell. A single cell at coarser resolution may then include both irrigated and nonirrigated areas from the original irrigation dataset, even as the whole cell is treated as irrigated in the model. This can result in greater irrigated areas and potentially higher 

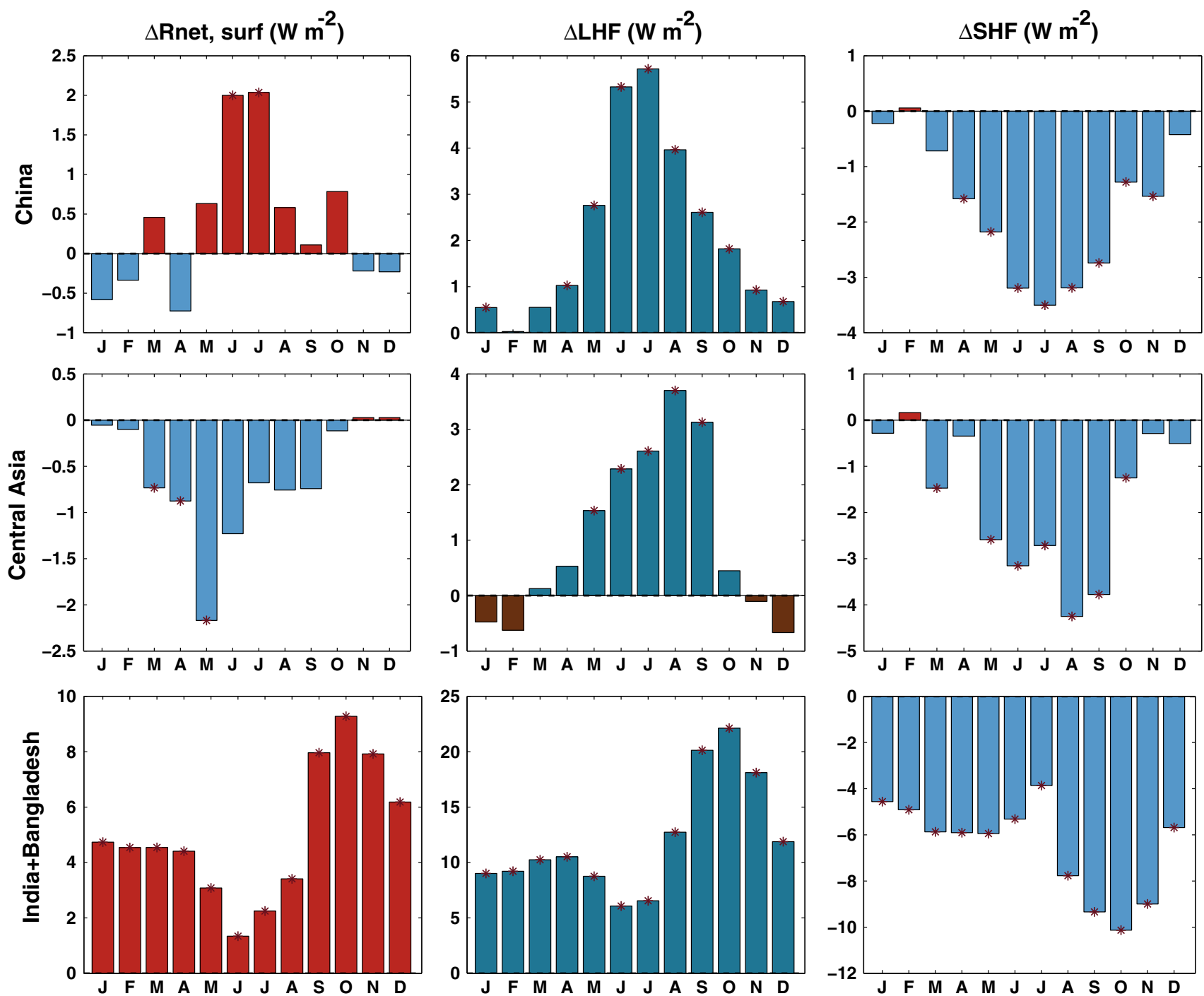

Fig. 10 For the same regions in Fig. 9 (China, Central Asia, India), differences (HIST + IRR - HIST) in net radiation at the surface (left column), surface latent heat flux (center column), and surface sensible heat flux (right column)

evapotranspiration rates and climate responses. To improve the realism of these responses, increases in spatial resolution of the model's land and vegetation modules would reduce overestimates of irrigated area. More directly, ModelE2-R should be modified to simulate the dynamics of a separate soil column for irrigated crops within each grid cell. These changes would lead (ideally) to improved soil moisture and evapotranspiration dynamics for both irrigated crops and other vegetation. Finally, there are still large uncertainties in how irrigation interacts with other anthropogenic forcings in GCMs. For example, anthopogenic aerosol forcing has important effects on the surface energy balance in many regions, which may affect the evaporative regime and evapotranspiration rates (Nazarenko and Menon 2005).

Where possible, we attempted to compare our results with other irrigation studies, but a comprehensive comparison was difficult for multiple reasons. For example, there is little standardization across modeling studies in the experimental setup, amount of irrigation forcing applied, and the model diagnostics reported. Analyses of irrigation effects on climate would therefore clearly benefit from standardized multi-model intercomparisons, similar to existing projects studying other land surfaceclimate interactions, such as GLACE (Koster et al. 2006; Seneviratne et al. 2013) and LUCID (Boisier et al. 2012; 

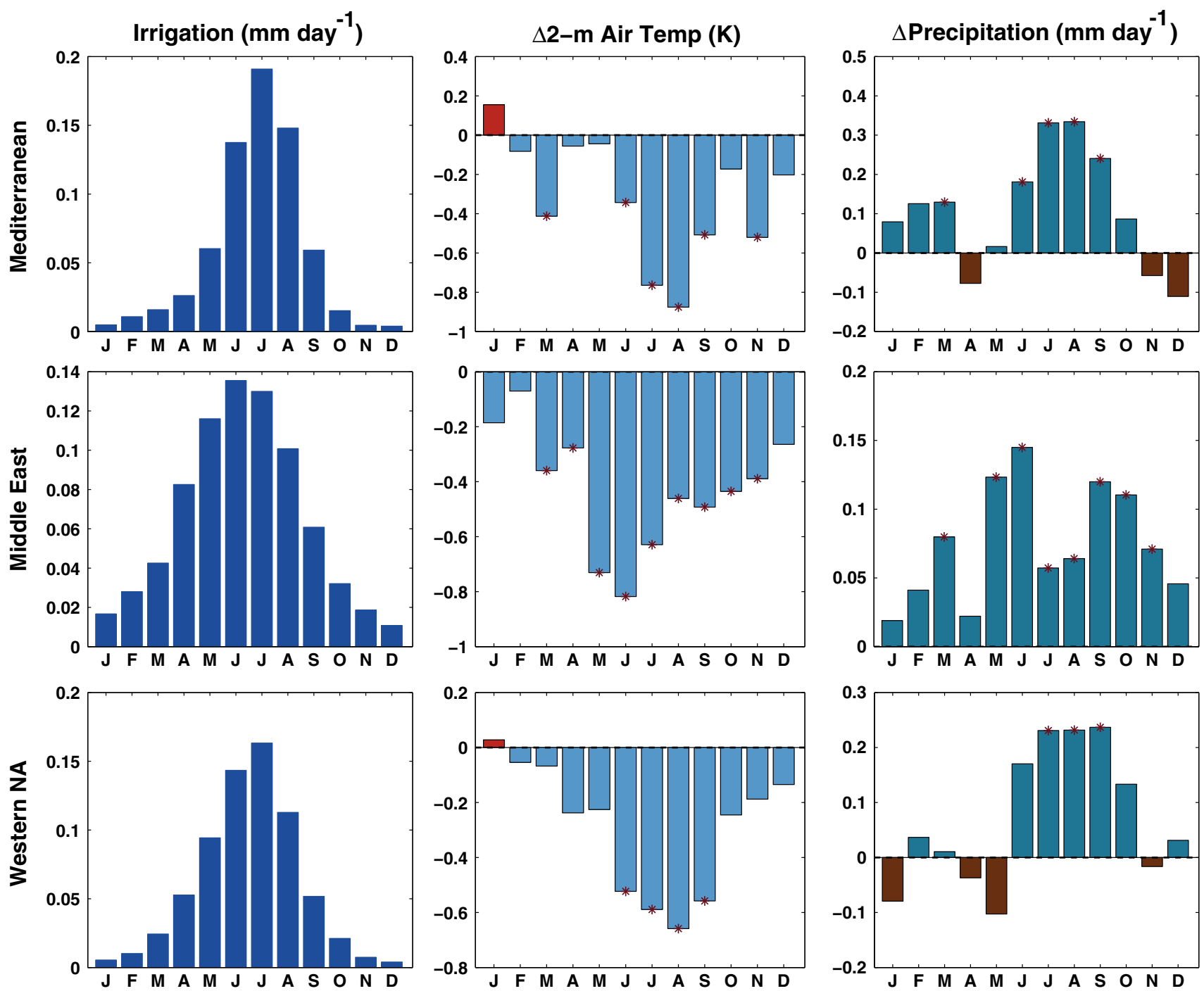

Fig. 11 For the Mediterranean $\left(13^{\circ} \mathrm{W}--30^{\circ} \mathrm{E}, 30^{\circ} \mathrm{N}--45^{\circ} \mathrm{N}\right.$, top row $)$, Middle East $\left(31^{\circ} \mathrm{E}--68^{\circ} \mathrm{E}, 10^{\circ} \mathrm{N}--44^{\circ} \mathrm{N}\right.$, middle row $)$, and Western North America $\left(125^{\circ} \mathrm{W}--90^{\circ} \mathrm{W}, 30^{\circ} \mathrm{N}--45^{\circ} \mathrm{N}\right.$, bottom row $)$, monthly irrigation rates in the HIST + IRR ensemble (left column), and monthly differences (HIST + IRR - HIST) in 2-m air temperature

Pitman et al. 2009). For irrigation, these intercomparisons are becoming increasingly tractable as GCM groups have begun integrating their own irrigation schemes, including the Community Earth System Model (CESM, Levis and Sacks 2011) and Laboratoire de Météorologie Dynamique (LMD-Z, Guimberteau et al. 2012). Ideally, such an intercomparison would, at minimum, (1) standardize the set of model diagnostics reported and analyzed (e.g., energy balance terms, temperature, etc.) and (2) use a common dataset of irrigation forcing, such as the WBMplus data set used here. Such a set of experiments would be especially helpful for highlighting model (center column) and precipitation (right column). Differences are calculated using the ensemble averages for 1981-2000. Significant differences at the $p \leq 0.05$ level, based on a two-sided Student's $t$ test, are indicated by the red stars

based uncertainties in the irrigation-climate response (e.g., model resolution, surface climate biases, etc.). Additionally, given the broad evidence presented here, and in other modeling and empirical studies, for a significant impact of irrigation on climate, we believe that irrigation should be included as another standard historical anthropogenic climate forcing in future multi-model assessments, such as the CMIP6 (Meehl et al. 2014). The importance of irrigation for historical (and future) climate can then be assessed in comparison to other important anthropogenic forcings, such as aerosols, land cover change, and GHGs. 

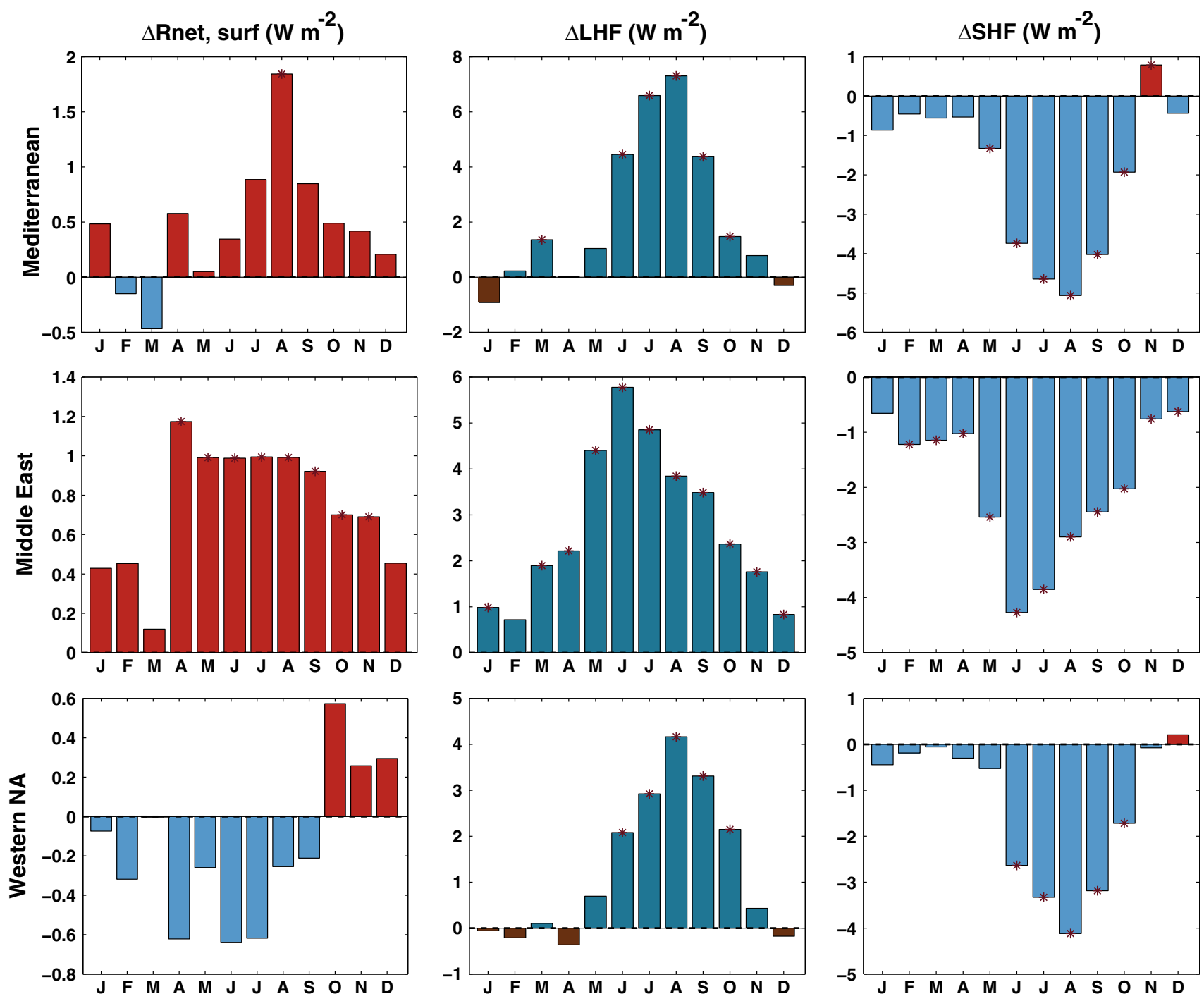

Fig. 12 For the same regions in Fig. 11 (Mediterranean, Middle East, Western North America), differences (HIST + IRR - HIST) in net radiation at the surface (left column), surface latent heat flux (center column), and surface sensible heat flux (right column)

Acknowledgments Simulations with the GISS ModelE2-R were made possible by the NASA High-End Computing (HEC) Program through the NASA Center for Climate Simulation (NCCS) at Goddard Space Flight Center. Development of ModelE2-R was supported by the NASA Modeling, Analysis and Prediction (MAP) Program. Funding support for BIC provided by NASA. The authors gratefully acknowledge funding for Interdisciplinary Global Change Research under NASA cooperative agreement NNX08AJ75A supported by the NASA Climate and Earth Observing Program. Two anonymous reviewers provided valuable comments that improved the quality of this manuscript. LDEO Publication number \#. Lamont contribution \#7808.

\section{References}

Barnston AG, Schickedanz PT (1984) The effect of irrigation on warm season precipitation in the southern Great Plains. J Clim Appl Meteorol 23(6):865-888. doi:10.1175/1520-0450(1984) $023<0865$ :TEOIOW $>2.0 . \mathrm{CO} ; 2$
Bellouin N, Mann GW, Woodhouse MT, Johnson C, Carslaw KS, Dalvi M (2013) Impact of the modal aerosol scheme GLOMAPmode on aerosol forcing in the Hadley Centre Global Environmental Model. Atmos Chem Phys 13(6):3027-3044. doi:10. 5194/acp-13-3027-2013

Boisier JP, de Noblet-Ducoudré N, Pitman AJ, Cruz FT, Delire C, van den Hurk BJJM, van der Molen MK, Müller C, Voldoire A (2012) Attributing the impacts of land-cover changes in temperate regions on surface temperature and heat fluxes to specific causes: results from the first LUCID set of simulations. J Geophys Res Atmos 117(D12). doi:10.1029/2011JD017106

Bonfils C, Lobell D (2007) Empirical evidence for a recent slowdown in irrigation-induced cooling. Proc Natl Acad Sci 104(34): 13,582-13,587. doi:10.1073/pnas.0700144104

Booth BBB, Dunstone NJ, Halloran PR, Andrews T, Bellouin N (2012) Aerosols implicated as a prime driver of twentiethcentury North Atlantic climate variability. Nature 484(7393): 228-232. doi:10.1038/nature10946

Boucher O, Myhre G, Myhre A (2004) Direct human influence of irrigation on atmospheric water vapour and climate. Clim Dyn 22(6):597-603. doi:10.1007/s00382-004-0402-4 
Chen F, Xie Z (2012) Effects of crop growth and development on regional climate: a case study over East Asian monsoon area. Clim Dyn 38(11-12):2291-2305. doi:10.1007/s00382-0111125-y

Cook BI, Puma MJ, Krakauer NY (2011) Irrigation induced surface cooling in the context of modern and increased greenhouse gas forcing. Clim Dyn 37(7-8):1587-1600. doi:10.1007/s00382010-0932-x

DeAngelis A, Dominguez F, Fan Y, Robock A, Kustu MD, Robinson D (2010) Evidence of enhanced precipitation due to Irrigation over the Great Plains of the United States. J Geophys Res Atmos 115. doi:10.1029/2010JD013892

Feddema JJ, Oleson KW, Bonan GB, Mearns LO, Buja LE, Meehl GA, Washington WM (2005) The importance of land-cover change in simulating future climates. Science 310(5754): 1674-1678. doi:10.1126/science. 1118160

Federer CA, Vörösmarty C, Fekete B (2003) Sensitivity of annual evaporation to soil and root properties in two models of contrasting complexity. J Hydrometeorol 4:1276-1290. doi:10. 1175/1525-7541(2003)004<1276:SOAETS $>2.0 . C O ; 2$

Freydank K, Siebert S (2008) Towards mapping the extent of irrigation in the last century: time series of irrigated area per country. Technical report 8. Institute of Physical Geography, University of Frankfurt, Frankfurt

Guimberteau M, Laval K, Perrier A, Polcher J (2012) Global effect of irrigation and its impact on the onset of the Indian summer monsoon. Clim Dyn 39(6):1329-1348. doi:10.1007/s00382-011$1252-5$

Hansen JE, Sato M, Ruedy R, Kharecha P, Lacis A, Miller R, Nazarenko L, Lo K, Schmidt GA, Russell G et al (2007) Climate simulations for 1880-2003 with GISS modelE. Clim Dyn 29(7):661-696. doi:10.1007/s00382-007-0255-8

He B, Bao Q, Li J, Wu G, Liu Y, Wang X, Sun Z (2013) Influences of external forcing changes on the summer cooling trend over East Asia. Clim Change 117(4):829-841. doi:10.1007/s10584-0120592-4

Jones PD, Lister DH, Osborn TJ, Harpham C, Salmon M, Morice CP (2012) Hemispheric and large-scale land-surface air temperature variations: an extensive revision and an update to 2010. J Geophys Res Atmos 117(D5). doi:10.1029/2011JD017139

Kosaka Y, Xie SP (2013) Recent global-warming hiatus tied to equatorial Pacific surface cooling. Nature. doi:10.1038/ nature 12534

Koster RD, Sud YC, Guo Z, Dirmeyer PA, Bonan G, Oleson KW, Chan E, Verseghy D, Cox P, Davies H, Kowalczyk E, Gordon CT, Kanae S, Lawrence D, Liu P, Mocko D, Lu CH, Mitchell K, Malyshev S, McAvaney B, Oki T, Yamada T, Pitman A, Taylor CM, Vasic R, Xue Y (2006) GLACE: the global landatmosphere coupling experiment. Part I: Overview. J Hydrometeorol 7(4):590-610. doi:10.1175/JHM510.1

Kueppers L, Snyder M, Sloan L (2007) Irrigation cooling effect: regional climate forcing by land-use change. Geophys Res Lett 34:1-5. doi:10.1029/2006GL028679

Kumar S, Dirmeyer PA, Merwade V, DelSole T, Adams JM, Niyogi D (2013) Land use/cover change impacts in CMIP5 climate simulations: a new methodology and 21 st century challenges. J Geophys Res Atmos 118(12):6337-6353. doi:10.1002/jgrd. 50463

Levis S, Sacks W (2011) Technical descriptions of the interactive crop management (CLM4CNcrop) and interactive irrigation models in version 4 of the Community Land Model. Technical report, National Center for Atmospheric Research

Lo MH, Famiglietti JS (2013) Irrigation in California's Central Valley strengthens the southwestern U.S. water cycle. Geophys Res Lett 40(2):301-306. doi:10.1002/grl.50108
Lobell DB, Bala G, Duffy PB (2006) Biogeophysical impacts of cropland management changes on climate. Geophys Res Lett 33(6). doi:10.1029/2005GL025492

Luyssaert S, Jammet M, Stoy PC, Estel S, Pongratz J, Ceschia E, Churkina G, Don A, Erb K, Ferlicoq M, Gielen B, Grunwald T, Houghton RA, Klumpp K, Knohl A, Kolb T, Kuemmerle T, Laurila T, Lohila A, Loustau D, McGrath MJ, Meyfroidt P, Moors EJ, Naudts K, Novick K, Otto J, Pilegaard K, Pio CA, Rambal S, Rebmann C, Ryder J, Suyker AE, Varlagin A, Wattenbach M, Dolman AJ (2014) Land management and landcover change have impacts of similar magnitude on surface temperature. Nat Clim Change 4(5):389-393. doi:10.1038/ nclimate 2196

Mahmood R, Keeling T, Foster SA, Hubbard KG (2013a) Did irrigation impact 20th century air temperature in the High Plains aquifer region? Appl Geogr 38:11-21. doi:10.1016/j.apgeog. 2012.11.002

Mahmood R, Pielke RA, Hubbard KG, Niyogi D, Dirmeyer PA, McAlpine C, Carleton AM, Hale R, Gameda S, BeltránPrzekurat A, Baker B, McNider R, Legates DR, Shepherd M, Du J, Blanken PD, Frauenfeld OW, Nair US, Fall S (2013b) Land cover changes and their biogeophysical effects on climate. Int J Climatol. doi:10.1002/joc.3736

Meehl GA, Moss R, Taylor KE, Eyring V, Stouffer RJ, Bony S, Stevens B (2014) Climate model intercomparisons: preparing for the next phase. Eos Trans Am Geophys Union 95(9):77-78. doi:10.1002/2014EO090001

Miller RL, Schmidt GA, Nazarenko LS, Tausnev N, Bauer SE, DelGenio AD, Kelley M, Lo KK, Ruedy R, Shindell DT et al (2014) CMIP5 historical simulations (1850-2012) with GISS ModelE2. J Adv Model Earth Syst. doi:10.1002/2013MS000266

Nazarenko L, Menon S (2005) Varying trends in surface energy fluxes and associated climate between 1960 and 2002 based on transient climate simulations. Geophys Res Lett 32(22). doi:10. 1029/2005GL024089

Pielke RA, Pitman A, Niyogi D, Mahmood R, McAlpine C, Hossain F, Goldewijk KK, Nair U, Betts R, Fall S, Reichstein M, Kabat $\mathrm{P}$, de Noblet N (2011) Land use/land cover changes and climate: modeling analysis and observational evidence. Wiley Interdiscip Rev Clim Change 2(6):828-850. doi:10.1002/wcc.144

Pitman AJ, de Noblet-Ducoudré N, Cruz FT, Davin EL, Bonan GB, Brovkin V, Claussen M, Delire C, Ganzeveld L, Gayler V, van den Hurk BJJM, Lawrence PJ, van der Molen MK, Müller C, Reick CH, Seneviratne SI, Strengers BJ, Voldoire A (2009) Uncertainties in climate responses to past land cover change: first results from the LUCID intercomparison study. Geophys Res Lett 36(14). doi:10.1029/2009GL039076

Puma MJ, Cook BI (2010) Effects of irrigation on global climate during the 20th century. J Geophys Res Atmos 115. doi:10.1029/ 2010JD014122

Qian Y, Giorgi F (2000) Regional climatic effects of anthropogenic aerosols? The case of southwestern China. Geophys Res Lett 27(21):3521-3524. doi:10.1029/2000GL011942

Rodell M, Velicogna I, Famiglietti JS (2009) Satellite-based estimates of groundwater depletion in India. Nature 460(7258):999-1002. doi: $10.1038 /$ nature08238

Russell GL, Miller JR, Rind D (1995) A coupled atmosphere-ocean model for transient climate change studies. Atmos-Ocean 33:683-730

Sacks WJ, Cook BI, Buenning N, Levis S, Helkowski JH (2009) Effects of global irrigation on the near-surface climate. Clim Dyn 33(2):159-175. doi:10.1007/s00382-008-0445-z

Santer BD, Painter JF, Bonfils C, Mears CA, Solomon S, Wigley TML, Gleckler PJ, Schmidt GA, Doutriaux C, Gillett NP, Taylor KE, Thorne PW, Wentz FJ (2013) Human and natural influences 
on the changing thermal structure of the atmosphere. Proc Natl Acad Sci. doi:10.1073/pnas.1305332110

Scanlon BR, Faunt CC, Longuevergne L, Reedy RC, Alley WM, McGuire VL, McMahon PB (2012) Groundwater depletion and sustainability of irrigation in the US High Plains and Central Valley. Proc Natl Acad Sci 109(24):9320-9325. doi:10.1073/ pnas. 1200311109

Schmidt GA, Kelley M, Nazarenko L, Ruedy R, Russell GL et al (2014) Configuration and assessment of the GISS ModelE2 contributions to the CMIP5 archive. J Adv Model Earth Syst 6(1):141-184. doi:10.1002/2013MS000265

Seneviratne SI, Wilhelm M, Stanelle T, van den Hurk B, Hagemann S, Berg A, Cheruy F, Higgins ME, Meier A, Brovkin V, Claussen M, Ducharne A, Dufresne JL, Findell KL, Ghattas J, Lawrence DM, Malyshev S, Rummukainen M, Smith B (2013) Impact of soil moisture-climate feedbacks on CMIP5 projections: first results from the GLACE-CMIP5 experiment. Geophys Res Lett. doi:10.1002/grl.50956

Shukla SP, Puma MJ, Cook BI (2013) The response of the South Asian summer monsoon circulation to intensified irrigation in global climate model simulations. Clim Dyn 1-16. doi:10.1007/ s00382-013-1786-9

Siebert S, Döll P, Feick S, Hoogeveen J (2005a) Global map of irrigated areas version 2.2. Technical report, Johann Wolfgang Goethe University, Frankfurt

Siebert S, Döll P, Hoogeveen J, Faures JM, Frenken K, Feick S (2005) Development and validation of the global map of irrigation areas. Hydrol Earth Syst Sci 9(5):535-547. doi:10.5194/hess-9535-2005

Siebert S, Burke J, Faures JM, Frenken K, Hoogeveen J, Döll P, Portmann FT (2010) Groundwater use for irrigation-a global inventory. Hydrol Earth Syst Sci 14(10):1863-1880. doi:10. 5194/hess-14-1863-2010

Taylor KE, Stouffer RJ, Meehl GA (2012) An overview of CMIP5 and the experiment design. Bull Am Meteorol Soc 93(4):485-498. doi:10.1175/BAMS-D-11-00094.1

Vörösmarty CJ, Federer CA, Schloss AL (1998) Potential evaporation functions compared on US watersheds: possible implications for global-scale water balance and terrestrial ecosystem modeling. J Hydrol 207(3-4):147-169. doi:10.1016/S00221694(98)00109-7

Wada Y, van Beek LPH, van Kempen CM, Reckman JWTM, Vasak S, Bierkens MFP (2010) Global depletion of groundwater resources. Geophys Res Lett 37(20). doi:10.1029/2010GL04 4571

Wisser D, Frolking S, Douglas EM, Fekete BM, Vörösmarty CJ, Schumann AH (2008) Global irrigation water demand: variability and uncertainties arising from agricultural and climate data sets. Geophys Res Lett 35(24). doi:10.1029/2008GL035296

Wisser D, Fekete BM, Vorosmarty CJ, Schumann A (2010) Reconstructing 20th century global hydrography: a contribution to the Global Terrestrial Network-Hydrology (GTN-H). Hydrol Earth Syst Sci 14:1-24. doi:10.5194/hess-14-1-2010 